\title{
Biocontrol of seed pathogens and growth promotion of common bean seedlings by Trichoderma harzianum
}

\author{
Daniel Diego Costa Carvalho(1), Sueli Corrêa Marques de Mello(2), Murillo Lobo Júnior ${ }^{(3)}$ \\ and Alaerson Maia Geraldine ${ }^{(3)}$
}

\begin{abstract}
(1)Universidade de Brasília, Departamento de Fitopatologia, Campus Universitário Darcy Ribeiro, CEP 70910-700 Brasília, DF, Brazil. E-mail: ufla-ddcc@bol.com.br ${ }^{(2)}$ Embrapa Recursos Genéticos e Biotecnologia, Parque Estação Biológica, Avenida W5 Norte (final), Caixa Postal 02372, CEP 70770-900 Brasília, DF, Brazil. E-mail: smello@cenargen.embrapa.br ${ }^{(3)}$ Embrapa Arroz e Feijão, Rodovia GO-462, Km 12, Fazenda Capivara, Zona Rural, Caixa Postal 179, CEP 75375-000 Santo Antônio de Goiás, GO, Brazil. E-mail: murillo@cnpaf.embrapa.br, alaersonmaia@hotmail.com
\end{abstract}

\begin{abstract}
The objective of this work was to evaluate isolates of Trichoderma harzianum regarding biocontrol of common bean seed-borne pathogens, plant growth promotion, and rhizosphere competence. Five isolates of T. harzianum were evaluated and compared with commercial isolate (Ecotrich), Carboxin+Thiram, and an absolute control. Bean seeds of the cultivar Jalo Precoce, contaminated with Aspergillus, Cladosporium, and Sclerotinia sclerotiorum, were microbiolized with antagonists, and seed health tests were carried out. Isolates were evaluated on autoclaved substrate and in field conditions. Ten days after sowing (DAS), plant length was measured. To test rhizosphere competence, isolates were applied in boxes containing autoclaved washed sand, and root colonization was evaluated at 10 DAS, using five plants per box. The most effective isolates in the seed health tests were: CEN287 and CEN289 to control Aspergillus; the commercial isolate to control Cladosporium; and CEN287 and CEN316 to control S. sclerotiorum. Isolates CEN289 and CEN290 promoted bean growth in greenhouse and field. Seed treatment with T. harzianum reduces the incidence of Aspergillus, Cladosporium, and S. sclerotiorum in 'Jalo Precoce' common bean seeds.
\end{abstract}

Index terms: Phaseolus vulgaris, Sclerotinia sclerotiorum, biological control, bioprospection, seed pathology.

\section{Biocontrole de patógenos em sementes e promoção do crescimento de plântulas de feijão comum por Trichoderma harzianum}

Resumo - O objetivo deste trabalho foi avaliar isolados de Trichoderma harzianum quanto ao biocontrole de patógenos veiculados por sementes de feijoeiro comum, à promoção do crescimento de plantas e à rizocompetência. Cinco isolados foram avaliados e comparados com um isolado comercial (Ecotrich), com Carboxin+Thiram, e com um controle negativo. Sementes de feijão da cultivar Jalo Precoce, contaminadas por Aspergillus, Cladosporium e Sclerotinia sclerotiorum, foram microbiolizadas com antagonistas e, em seguida, foram realizados testes de sanidade de sementes. Os isolados foram avaliados em substrato autoclavado e em condições de campo. Aos 10 dias após o semeio (DAS), mediu-se o comprimento das plantas. Para os testes de rizocompetência, os isolados foram pulverizados sobre caixas contendo areia lavada autoclavada, e a colonização das raízes foi avaliada aos 10 DAS, tendo-se utilizado cinco plantas por caixa. Os isolados mais efetivos nos testes de sanidade de sementes foram: CEN287 e CEN289 para controle de Aspergillus; o isolado comercial para Cladosporium; e CEN287 e CEN316 para S. sclerotiorum. Os isolados CEN289 e CEN290 promoveram o crescimento do feijoeiro em casa de vegetação e em campo. O tratamento de sementes com T. harzianum reduz a incidência de Aspergillus, Cladosporium e S. sclerotiorum em sementes do feijoeiro comum 'Jalo Precoce'.

Termos para indexação: Phaseolus vulgaris, Sclerotinia sclerotiorum, controle biológico, bioprospecção, patologia de sementes.

\section{Introduction}

The incidence of pathogens in common bean (Phaseolus vulgaris L.) seeds causes losses in the physiological seed quality and unevenness in germination as well as in the initial stand establishment (Carvalho et al., 2011). In addition, seeds are an important vehicle for the introduction and the dissemination of pathogens in uninfested regions (Ito et al., 2003).

Various pathogens of epidemiological importance can cause damages to seed quality in common bean crops, such as Sclerotinia sclerotiorum (Lib.) de Bary. These pathogens can survive in seeds for more

Pesq. agropec. bras., Brasília, v.46, n.8, p.822-828, ago. 2011 
than three years and may establish diseases in new areas early in the crop cycle (Tu, 1988). In infested soils, $S$. sclerotiorum is responsible for white mold, one of the most destructive disease of common bean, with up to $100 \%$ yield losses (Lobo Júnior et al., 2009).

The fungi Aspergillus and Cladosporium are associated with common bean seeds during storage and are able to inflict damages on germination and vigor, especially in nontreated seeds (Ito et al., 2003; Zucchi \& Melo, 2009).

Seed treatment with fungicides or biocontrol agents reduce pathogen dissemination, contributing to higher plant density stands (Sartori et al., 2004). These treatments eliminate pathogens and protect against diseases during pre and post emergence, being fundamental for a good crop establishment. According to Ito et al. (2003), seed treatments require small amounts of fungicide, i.e., 0.1 to $0.5 \%$ of the total production cost.

According to Pomella \& Ribeiro (2009), biocontrol with Trichoderma can reduce the number of chemical fungicide applications and possibly eliminate this practice, depending on environmental conditions, disease severity, and management. Seed chemical treatments may be replaced by biological treatments, bringing economic, social, and environmental benefits.

Some isolates can also stimulate plant growth (Harman et al., 2004; Vinale et al., 2008) due to rhizospheric colonization (rhizosphere competence), production of substances that stimulate plant growth, and solubilization of nutrients close to the roots, which allows these substances to be assimilated by the plant (Harman, 2000). Therefore, the benefits provided by Trichoderma colonization make rhizosphere competence an important feature for selecting potential biocontrol agents for disease control (Harman et al., 2004).

Several products based on Trichoderma are recommended for substrate and seed treatments in the market (Ethur et al., 2007; Mertz et al., 2009). However, studies on seed treatments using biological fungicides are still scarce (Mertz et al., 2009).

The objective of this work was to evaluate isolates of T. harzianum regarding biocontrol of common bean seed-borne pathogens, plant growth promotion, and rhizosphere competence.

\section{Materials and Methods}

Five Trichoderma isolates belonging to the fungi collection for biological control of plant pathogens of Embrapa Recursos Genéticos e Biotecnologia were evaluated. These isolate were identified as T. harzianum (Samuels et al., 2009). The experiments were carried out at Embrapa Arroz e Feijão, in Santo Antônio de Goiás, GO, Brazil.

In order to obtain inoculum, seven-day-old agar plugs ( $5 \mathrm{~mm}$ ) were isolated from CEN287, CEN288, CEN289, CEN290, and CEN316 cultures and transferred to $250 \mathrm{~mL}$ flasks (six plugs per flask), containing parboiled rice (15 g per flask), previously moistened $\left(60 \% \mathrm{p} \mathrm{v}^{-1}\right)$ and autoclaved $\left(121^{\circ} \mathrm{C}\right.$ for $\left.40 \mathrm{~min}\right)$. Flasks were kept in BOD at $25^{\circ} \mathrm{C}$, under a 12 -hour light exposure period. After seven days, spores were collected by flushing with distilled water and filtered through sterile gauze. The obtained suspension concentration was adjusted at $2.5 \times 10^{8}$ conidia $\mathrm{mL}^{-1}$ in a Neubauer chamber.

Seed health tests were performed using the blotter method (Regras para Análise de Sementes, 2009). Common beans seeds of the cultivar Jalo Precoce, naturally contaminated by Aspergillus and Cladosporium, were treated with T. harzianum isolates and Ecotrich SC, commercial isolate of T. harzianum, (Ballagro Agro Tecnologia Ltda., Atibaia, SP, Brazil), with $2 \mathrm{~mL}$ of a $2.5 \times 10^{8}$ conidia $\mathrm{mL}^{-1}$ suspension per $100 \mathrm{~g}$ of seeds. Seeds treated with Carboxin+Thiram (300 mL per $100 \mathrm{~kg}$ of seeds; $200 \mathrm{~g} \mathrm{~L}^{-1}$ of carboxin and $200 \mathrm{~g} \mathrm{~L}^{-1}$ of thiram) and nontreated seeds were used as positive and negative controls, respectively.

Afterwards, 25 treated seeds were placed into acrylic transparent "gerboxes" and kept at $-20^{\circ} \mathrm{C}$ for 24 hours. After this period, samples were incubated in a growth chamber at $20^{\circ} \mathrm{C}$ and $98 \%$ relative humidity, under 12 hours of light exposure, for seven days. Samples were evaluated individually, and seeds were examined in a stereomicroscope. To confirm the presence of each fungal genus, semi-permanent microscope slides containing biological material were prepared and analyzed in a light microscope. The experiment was carried out in a completely randomized block design, with eight replicates of 25 seeds per treatment (Marino \& Mesquita, 2009).

The water restriction technique was used to obtain seeds contaminated with $S$. sclerotiorum (isolate C-54-01), using PDA medium + mannitol at -1.0 MPa (Costa et al., 2003). The seeds tested (56 g) were 
sterilized with $1 \%$ sodium hypochlorite and placed on the $S$. sclerotiorum colonies. Plates were incubated for five days for seed colonization.

Seeds contaminated with S. sclerotiorum were treated with isolates of $T$. harzianum and with the commercial isolate, as in the blotter test. After this procedure, 50 seeds were evenly distributed on two layers of germitest paper, moistened with distilled water, covered with a third moistened germitest paper sheet and then rolled (Regras para Análise de Sementes, 2009). Rolls were kept in a growth chamber at $20^{\circ} \mathrm{C}$ and $98 \%$ relative humidity for seven days (Parisi et al., 2006). Then, the rolls were moistened with distilled water and incubated in a refrigerator at $8^{\circ} \mathrm{C}$ for 10 days, without light incidence. Fungi incidence was evaluated by observing the presence of the typically white mycelium of $S$. sclerotiorum with black, spherical, and irregular sclerotia, with 2 to $10 \mathrm{~mm}$, around the infected seeds and seedlings (Regras para Análise de Sementes, 2009). The experiment was carried out with four replicates of 50 seeds, in a completely randomized block design (Gomes et al., 2009), using the same controls as in the blotter test.

Seeds contaminated with S. sclerotiorum and healthy seeds treated with Trichoderma were both subjected to the germination test, which was carried out in a completely randomized block design, with four replicates of 50 seeds per treatment (Gomes et al., 2009). Seeds were incubated in a germinator (De Leo e Cia Ltda., Porto Alegre, RS, Brazil) at $25^{\circ} \mathrm{C}$ for nine days. To evaluate the percentage of abnormal seedlings (seedlings exhibiting necrosis along the roots, hypocotyls and cotyledons, and seminal and secondary stunted and malformed roots or absence of secondary roots), the number of normal seedlings (absence of necrosis and pathogens, seminal and secondary roots without deformations) and dead seeds was estimated, according to the rules for seed testing (Regras para Análise de Sementes, 2009).

In order to test growth promotion, each plastic pot (500 mL capacity) containing autoclaved commercial substrate Plantmax received $25 \mathrm{~mL}$ of a spore suspension at $2 \times 10^{8}$ conidia $\mathrm{mL}^{-1}$ of $T$. harzianum $\left(5 \times 10^{9}\right.$ conidia per $500 \mathrm{~g}$ of substrate). Immediately after the procedure, five seeds of 'Jalo Precoce' common bean were sown in each pot. Treatments consisted of: autoclaved substrate treated with CEN287, CEN288, CEN289, CEN290, CEN316, and with the commercial isolate; seeds treated with Carboxin+Thiram $(300 \mathrm{~mL}$ per $100 \mathrm{~kg}$ of seeds) in autoclaved substrate, without Trichoderma; and a negative control with nontreated seeds, sown in autoclaved commercial substrate. Four pots were used per treatment. After 14 days, the shoot and root length of 12 plants per treatment were measured. Length measurements were taken from plants selected randomly, with three plants being from the same pot.

The field experiment was carried out under center pivot irrigation, in July and August 2009. Treatments consisted of: seeds and furrows treated with CEN287, CEN288, CEN289, CEN290, CEN316, and commercial isolate; seeds treated with Carboxin+Thiram $(300 \mathrm{~mL}$ per $100 \mathrm{~kg}$ of seeds), sown into furrows without application of Trichoderma; and nontreated seeds sown in furrows without application of Trichoderma as a negative control. An area of $288 \mathrm{~m}^{2}(24 \times 12 \mathrm{~m})$ was prepared and furrowed, and $400 \mathrm{~kg} \mathrm{ha}^{-1}$ of NPK 5-25-15 fertilizer were applied. A $40 \mathrm{~mL}$ per linear meter suspension of $T$. harzianum at $5 \times 10^{7}$ conidia $\mathrm{mL}^{-1}$ was sprayed in the furrows with a manual sprayer $(550 \mathrm{~mL})$ $\left(2 \times 10^{9}\right.$ conidia $\left.\mathrm{m}^{-1}\right)$. Then, seeds previously treated with isolates of Trichoderma $\left(2 \mathrm{~mL}\right.$ of suspension at $2.5 \times 10^{8}$ conidia $\mathrm{mL}^{-1}$ per $100 \mathrm{~g}$ of seeds) were sown ( 15 seeds per meter). Each treatment consisted of four experimental plots with four 2.0-m length rows, with intra-row spacing of $0.5 \mathrm{~m}$, and $1 \mathrm{~m}$ between plots, arranged in a completely randomized block design. Emergence was recorded eight days after sowing (DAS) by counting the number of seedlings emerged in the two central rows. At 10 DAS, four adjacent plants were removed per plot, according to Araújo \& Teixeira (2008), from the middle third of the main row, without damaging the roots. Then, the shoot and root lengths of 16 plants per treatment were measured.

For the rhizosphere competence assay, seeds were treated with $T$. harzianum $(2 \mathrm{~mL}$ of suspension at $2.5 \times 10^{8}$ conidia $\mathrm{mL}^{-1}$ per $100 \mathrm{~g}$ of seeds) and sown in plastic boxes $(30 \times 40 \mathrm{~cm})$, containing autoclaved washed sand. Treatments consisted of: CEN287, CEN288, CEN289, CEN290, CEN316, commercial isolate, and nontreated seeds as negative control, sown in boxes with sand, without Trichoderma. Four boxes were used per treatment, and each box received 50 seeds. A randomized complete block design was used. After sowing, a 100-mL suspension of $T$. harzianum at $5 \times 10^{7}$ conidia $\mathrm{mL}^{-1}$ was sprayed in each box. At 10 DAS, emergence on sand was assessed, and five plants per box were collected. Roots from collected plants were washed, excised in two segments, from the crown to the next $5 \mathrm{~cm}$ and from the median $5 \mathrm{~cm}$ to the root tip, using a sterilized scalpel. 
Subsequently, roots obtained from each segment were chopped $(1 \mathrm{~cm})$. Fragments from each treatment were separately packed in sterilized Petri dishes, sealed, and taken to a dark incubation room at $22^{\circ} \mathrm{C}$ for 48 hours, for natural root drying. Root fragments were sown on Trichoderma selective medium - TSM $(0.12 \mathrm{~g}$ of $\mathrm{KH}_{2} \mathrm{PO}_{4}, 0.26 \mathrm{~g}$ of $\mathrm{MgSO}_{4} .7 \mathrm{H}_{2} \mathrm{O}, 0.26 \mathrm{~g}$ of $\mathrm{KNO}_{3}$, $1.0 \mathrm{~g}$ of $\mathrm{CaCl}_{2} .2 \mathrm{H}_{2} \mathrm{O}, 1.0 \mathrm{~g}$ of $\mathrm{Ca}\left(\mathrm{NO}_{3}\right)_{2}, 0.05 \mathrm{~g}$ of citric acid, $1.0 \mathrm{~mL}$ of Igepal, $2.0 \mathrm{~g}$ of saccharose, $18.0 \mathrm{~g}$ of agar, $0.0025 \mathrm{~g}$ of vinclozolin, $1,000 \mathrm{~mL}$ of distilled water). Ten fragments per Petri dish $(9 \mathrm{~cm})$ were used. For each isolate, 16 dishes were prepared (eight dishes per segment), with two plates used for every five-plant group from the same box. After incubation for five days in $\mathrm{BOD}$ at $25^{\circ} \mathrm{C}$, the percentage of fragments colonized by $T$. harzianum was estimated. The rhizosphere competence test was carried out twice.

Results were subjected to analysis of variance and to the Scott-Knott test at 5\% probability, using the Sisvar software (Ferreira, 2008).

\section{Results and Discussion}

Seed pathology analyses (blotter test) indicated that Carboxin+Thiram is the best fungicide to control storage fungi on 'Jalo Precoce' common bean seeds (Table 1). Among Trichoderma isolates, Ecotrich SC showed a significantly higher performance, reducing in $67 \%$ the incidence of Cladosporium on seeds, in comparison to the negative control, followed by T. harzianum CEN287 and CEN316 isolates, with reductions of 41 and $40 \%$, respectively. The other three isolates - CEN288, CEN289, and CEN290 - also showed significant differences when compared to the negative control. The antagonist action of T. harzianum on the pathogen occurred through a mechanism known as hyperparasitism, as reported in experimental conditions by Barbosa et al. (2001), which observed mycelium wilt and sporulation within $C$. herbarum hyphae.

The incidence of Aspergillus was lower in all treatments in comparison to the negative control. Again, the chemical control was the most effective, controlling $100 \%$ of the pathogen. CEN287 and CEN289 reduced the incidence of Aspergillus in 56 and $61 \%$, respectively, showing more efficacy than the other isolates of T. harzianum and the commercial isolate. Although several mechanisms may occur simultaneously in disease biocontrol when Trichoderma is used, Agüero et al. (2008) reported antibiosis as the principal mechanism involved in the control of A. flavus in maize seeds. Exposure of A. flavus to volatile metabolites produced by $T$. harzianum caused a reduction of $31.7 \%$ in the pathogen biomass, in seeds (Agüero et al., 2008).

All treatments have shown efficacy in controlling $S$. sclerotiorum in common bean seeds. Among them, Carboxin+Thiram stood out, reducing the incidence of the pathogen in 98\%. Isolates CEN287 and CEN316 were statistically similar to the chemical treatment, and highly specific in controlling S. sclerotiorum, allowing reductions of 90 and $92 \%$ in the incidence of the pathogen, respectively.

The specificity of CEN316 in parasitizing hyphae of $S$. sclerotiorum in vitro was reported by Oliveira et al. (2008). For CEN287, this ability was verified in vitro in studies with Fusarium oxysporum f. sp.

Table 1. Effect of treatments on fungi incidence in seeds, on seed germination, and on seedling growth of 'Jalo Precoce' common bean plants ${ }^{(1)}$.

\begin{tabular}{|c|c|c|c|c|c|}
\hline \multirow[t]{2}{*}{ Treatment } & \multicolumn{3}{|c|}{ Fungi incidence (\%) } & \multicolumn{2}{|c|}{ Germination ( $\%$ of normal seedlings) } \\
\hline & Cladosporium & Aspergillus & Sclerotinia sclerotiorum & Uninoculated seeds & Inoculated Sclerotinia sclerotiorum \\
\hline CEN287 & $57.0 \mathrm{c}$ & $22.0 \mathrm{~b}$ & $5.0 \mathrm{a}$ & $94.5 \mathrm{bA}$ & $92.0 \mathrm{bA}$ \\
\hline CEN288 & $83.0 \mathrm{e}$ & $29.0 \mathrm{c}$ & $12.0 \mathrm{~b}$ & $94.5 \mathrm{bB}$ & $85.0 \mathrm{bA}$ \\
\hline CEN289 & $69.5 \mathrm{~d}$ & $19.5 b$ & $11.5 b$ & $94.0 \mathrm{bA}$ & $90.5 \mathrm{bA}$ \\
\hline CEN290 & $81.0 \mathrm{e}$ & $35.0 \mathrm{c}$ & $11.5 b$ & $90.5 \mathrm{aA}$ & $89.5 \mathrm{bA}$ \\
\hline CEN316 & $59.0 \mathrm{c}$ & $32.0 \mathrm{c}$ & $4.0 \mathrm{a}$ & $96.0 \mathrm{bA}$ & $91.0 \mathrm{bA}$ \\
\hline Commercial isolate & $32.0 \mathrm{~b}$ & $31.0 \mathrm{c}$ & $14.0 \mathrm{~b}$ & $98.0 \mathrm{bB}$ & $84.5 \mathrm{bA}$ \\
\hline Carboxin+Thiram & $0.0 \mathrm{a}$ & $0.0 \mathrm{a}$ & $1.0 \mathrm{a}$ & $95.5 \mathrm{bB}$ & $89.5 \mathrm{bA}$ \\
\hline Negative control & $97.0 \mathrm{f}$ & $49.5 \mathrm{~d}$ & $52.0 \mathrm{c}$ & $90.5 \mathrm{aB}$ & $76.0 \mathrm{aA}$ \\
\hline Mean & - & - & - & $94.2 \mathrm{~B}$ & $87.2 \mathrm{~A}$ \\
\hline CV $(\%)$ & 13.51 & 24.34 & 22.76 & 2.87 & 5.17 \\
\hline
\end{tabular}

${ }^{(1)}$ Means followed by equal letters, lowercase in the columns and uppercase in the rows, do not differ by the Scott-Knott test at $5 \%$ probability. 
phaseoli - another soil-borne pathogen (Carvalho et al., 2008). Among the known biological control mechanisms, hyperparasitism is the most effective in controlling $S$. sclerotiorum in bean seeds treated with CEN316 and CEN287. A possible explanation for the antagonism of these two isolates against the pathogen, in contrast to the other Trichoderma isolates, could be the performance of biological control mechanisms, including hyperparasitism, which can vary between species and among isolates of the same species (Martins-Corder \& Melo, 1998; Louzada et al., 2009).

Carvalho et al. (2011) reported lower efficacy in the biocontrol of $F$. oxysporum f. sp. phaseoli in seeds, with Carboxin+Thiram responsible for $73 \%$ reduction in the pathogen, while the biological treatment provided decreases of 35 to $51 \%$.

The results of the germination test with seeds naturally contaminated with Cladosporium and Aspergillus showed that only CEN290 did not differ from the negative control as to the percentage of normal seedlings. Even with the high incidence of Cladosporium (97\%) and Aspergillus (49.5\%), the percentage of normal seedlings at nine days was $90.5 \%$, in the negative control (Table 1). In general, the incidence of pathogens does not necessarily mean abnormal germination and origin of abnormal seedlings (França Neto \& Henning, 1984).

Seed pathogens can be limited to the seed coat. During emergence and with cotyledons detachment, the transmission of the fungi is prevented, resulting in healthy seedlings (Mertz et al., 2009). This escape mechanism was also observed by Henning \& França Neto (1980) in soybean seeds with high levels of Phomopsis. The seeds were able to germinate and to emerge when sown in sand substrate, since adequate moisture and temperature were provided.

In seeds contaminated by $S$. sclerotiorum, chemical and biological treatments were similar, providing a significantly higher percentage of normal seedlings than the negative control. Seeds treated with CEN287, CEN289, CEN290, and CEN316 were not affected by the $S$. sclerotiorum pathogen regarding germination. Seeds produced normal seedlings after nine days in the germinator (Table 1). However, the general means of the treatments showed significant reduction in germination after seeds were contaminated by $S$. sclerotiorum. In addition, seed treatments with
$2 \mathrm{~mL}$ of suspension at $2.5 \times 10^{8}$ conidia $\mathrm{mL}^{-1}$ of $T$. harzianum per $100 \mathrm{~g}$ of seeds did not cause any toxicity to germination (Carvalho et al., 2011).

Root length and total length means of CEN289, CEN290, and Carboxin+Thiram were higher than that of the negative control, while shoot length means were statistically similar in all treatments (Table 2). The ability of Trichoderma in promoting common bean early growth was reported by Hoyos-Carvajal et al. (2009) and confirmed in the present study. This effect was able to compensate the statistical inferiority of CEN289 and CEN290 when compared to CEN287 and CEN316 in the biocontrol of $S$. sclerotiorum in seeds. Despite allowing a higher incidence of the pathogen on seeds, CEN289 and CEN290 provided percentages of normal seedlings similar to CEN287 and CEN316 in the germination test, when seeds contaminated by $S$. sclerotiorum were used.

The results of the field experiment confirmed the effects of CEN289, CEN290, and Carboxin+Thiram in increasing plant growth (Table 3). As observed in the greenhouse, root and total length means of these three treatments were superior to those of the negative control and of the other Trichoderma isolates. Shoot length means were similar in all treatments and varied between 7.86 and $9.42 \mathrm{~cm}$.

Regarding emergence, the results obtained in the greenhouse (74 to $85 \%$ ) and in the field (68 to 83\%) were similar for all treatments. These results indicate the benefits of biological control in the early growth of common beans, which is essential for an adequate

Table 2. Emergence in sand 10 days after sowing (DAS), and root, shoot, and total length of 'Jalo Precoce' common bean plants (14 DAS) grown in substrate treated with Trichoderma harzianum under greenhouse conditions ${ }^{(1)}$.

\begin{tabular}{|c|c|c|c|c|}
\hline \multirow[t]{2}{*}{ Treatment } & \multirow{2}{*}{$\begin{array}{l}\text { Emergence } \\
\text { in sand }(\%)\end{array}$} & \multicolumn{3}{|c|}{ Length (cm) } \\
\hline & & Shoot & Root & Total \\
\hline CEN287 & 81 & 18.21 & $14.52 \mathrm{a}$ & $32.73 a$ \\
\hline CEN288 & 85 & 18.59 & $14.28 \mathrm{a}$ & $32.87 \mathrm{a}$ \\
\hline CEN289 & 76 & 19.26 & $16.03 \mathrm{~b}$ & $35.29 b$ \\
\hline CEN290 & 80 & 18.21 & $16.90 \mathrm{~b}$ & $35.11 b$ \\
\hline CEN316 & 77 & 19.50 & $14.31 \mathrm{a}$ & $33.81 \mathrm{a}$ \\
\hline Commercial isolate & 83 & 17.89 & $14.87 \mathrm{a}$ & $32.76 \mathrm{a}$ \\
\hline Carboxin+Thiram & 85 & 18.65 & $16.35 b$ & $35.00 \mathrm{~b}$ \\
\hline Negative control & 74 & 19.21 & $14.18 \mathrm{a}$ & $33.39 \mathrm{a}$ \\
\hline $\mathrm{CV}(\%)$ & 12.41 & 8.67 & 12.07 & 6.62 \\
\hline
\end{tabular}

${ }^{(1)}$ Means followed by equal letters, in the columns, do not differ by the Scott-Knott test, at 5\% probability. 
stand establishment. According to Harman (2000), T. harzianum (isolate T-22) is a plant growth promoter in soybean (Glycine max L.) and maize (Zea mays L.), besides increasing pepper (Capsicum annuum L.) yield, in comparison to plants not treated with this fungus. In the present study, increases in plant growth provided by Trichoderma were isolate-dependent.

Isolates CEN288, CEN289, and CEN290 showed similar results, superior to those of the other isolates as to the percentage of root fragments colonized by Trichoderma in the initial $5 \mathrm{~cm}$ (Table 4). CEN287 and CEN316 had the lowest percentages of root colonization in the initial and final $5 \mathrm{~cm}$. Colonization by $T$. harzianum of negative control roots was not detected.

According to Vinale et al. (2008), species of the genus Trichoderma are able to solubilize nutrients

Table 3. Field emergence, shoot, root, and total length of 'Jalo Precoce' common bean plants grown in furrows treated with Trichoderma harzianum under field conditions ${ }^{(1)}$.

\begin{tabular}{lcccc}
\hline Treatment & $\begin{array}{c}\text { Field emergence } \\
\text { (\%) }\end{array}$ & \multicolumn{3}{c}{ Length $(\mathrm{cm})$} \\
\cline { 3 - 5 } & 71 & Shoot & Root & Total \\
\hline CEN287 & 81 & 8.86 & $10.14 \mathrm{a}$ & $18.00 \mathrm{a}$ \\
CEN288 & 83 & 8.73 & $10.14 \mathrm{a}$ & $18.65 \mathrm{a}$ \\
CEN289 & 79 & 9.42 & $13.08 \mathrm{~b}$ & $20.81 \mathrm{~b}$ \\
CEN290 & 72 & 9.42 & $9.95 \mathrm{a}$ & $19.37 \mathrm{a}$ \\
CEN316 & 81 & 9.13 & $10.69 \mathrm{a}$ & $19.82 \mathrm{a}$ \\
Commercial isolate & 81 & 9.26 & $11.65 \mathrm{~b}$ & $20.91 \mathrm{~b}$ \\
Carboxin+Thiram & 68 & 8.83 & $10.84 \mathrm{a}$ & $19.67 \mathrm{a}$ \\
Negative control & 14.59 & 17.26 & 16.23 & 12.17 \\
\hline CV (\%) & & & &
\end{tabular}

${ }^{(1)}$ Means followed by equal letters, in the columns, do not differ by the Scott-Knott test at $5 \%$ probability.

Table 4. Rhizosphere competence (\%) of Trichoderma harzianum applied on 'Jalo Precoce' common bean seeds and on autoclaved washed sand, under greenhouse conditions ${ }^{(1)}$.

\begin{tabular}{lcc}
\hline Treatment & \multicolumn{2}{c}{ Bean roots colonized by Trichoderma harzianum $(\%)$} \\
\cline { 2 - 3 } & Initial $5 \mathrm{~cm}$ & Final $5 \mathrm{~cm}$ \\
\hline CEN287 & $37.5 \mathrm{bA}$ & $22.5 \mathrm{bA}$ \\
CEN288 & $88.7 \mathrm{~dB}$ & $52.5 \mathrm{cA}$ \\
CEN289 & $82.5 \mathrm{~dB}$ & $28.8 \mathrm{bA}$ \\
CEN290 & $92.5 \mathrm{dA}$ & $81.2 \mathrm{dA}$ \\
CEN316 & $30.0 \mathrm{bA}$ & $15.0 \mathrm{aA}$ \\
Commercial isolate & $60.0 \mathrm{cB}$ & $35.0 \mathrm{bA}$ \\
Negative control & $0 \mathrm{aA}$ & $0 \mathrm{aA}$ \\
\hline Mean & $65.2 \mathrm{~B}$ & $39.2 \mathrm{~A}$ \\
CV (\%) & 17.49 & 32.13 \\
\hline
\end{tabular}

${ }^{(1)}$ Means followed by equal letters, lowercase in the columns and uppercase in the rows, do not differ by the Scott-Knott test at $5 \%$ probability. from the rhizosphere, allowing them to be absorbed by roots, and to produce secondary metabolites that can act as auxin-like compounds.

Hoyos-Carvajal et al. (2009) demonstrated that the early growth of common bean plants up to stage V3 was increased with the presence of rhizosphere competent Trichoderma. Among the top seven isolates selected by these authors, some have not proven to produce antibiotics, phytohormones or siderophores and were not able to solubilize phosphates. These results indicate the importance of rhizosphere competence in promoting early growth of bean plants. In the present study, CEN289 and CEN290, the two isolates able to promote early growth of 'Jalo Precoce' common bean seeds in the greenhouse and in the field, were among the three rhizosphere competent isolates tested.

General mean percentages of the colonized roots showed decreases from $65.2 \%$ (initial $5 \mathrm{~cm}$ ) to $39.2 \%$ (final $5 \mathrm{~cm}$ ) (Table 4). Among the four isolates with the highest percentages of root colonization (Commercial isolate, CEN288, CEN289, and CEN290), only CEN290 maintained similar colonization percentages in the two profiles: 92.5 and $81.2 \%$ in the initial and final $5 \mathrm{~cm}$, respectively. These results indicate that CEN290 is the best isolate to promote early growth of 'Jalo Precoce' common bean and to colonize the entire root length.

\section{Conclusions}

1. Seed treatment with Trichoderma harzianum reduces the incidence of Aspergillus, Cladosporium, and Sclerotinia sclerotiorum in 'Jalo Precoce' common bean seeds.

2. Isolates CEN289 and CEN290 of T. harzianum have the ability to colonize common bean roots.

\section{Acknowledgements}

To Conselho Nacional de Desenvolvimento Científico e Tecnológico and to Fundação de Apoio à Pesquisa do Distrito Federal, for financial support.

\section{References}

AGÜERO, L.E.M.; ALVARADO, R.; MARTÍNEZ, A.; DORTA, B. Inhibition of Aspergillus flavus growth and aflatoxin b1 production in stored maize grains exposed to volatile compounds of Trichoderma harzianum Rifai. Interciência, v.33, p.219-222, 2008.

ARAÚJO, A.P.; TEIXEIRA, M.G. Relationships between grain yield and accumulation of biomass, nitrogen and phosphorus in 
common bean cultivars. Revista Brasileira de Ciência do Solo, v.32, p.1977-1986, 2008.

BARBOSA, M.A.G.; REHN, K.G.; MENEZES, M.; MARIANO, R.L.R. Antagonism of Trichoderma species on Cladosporium herbarum and their enzimatic characterization. Brazilian Journal of Microbiology, v.32, p.98-104, 2001.

CARVALHO, D.D.C.; MELLO, S.C.M.; LOBO JUNIOR, M.; SILVA, M.C. Controle de Fusarium oxysporum f.sp. phaseoli in vitro e em sementes, e promoção do crescimento inicial do feijoeiro comum por Trichoderma harzianum. Tropical Plant Pathology, v.36, p.36-42, 2011.

CARVALHO, D.D.C.; OLIVEIRA, T.A.S.; BRAÚNA, L.M.; MELLO, S.C.M. Isolados de Trichoderma sp. antagônicos a Fusarium oxysporum. Brasília: Embrapa Recursos Genéticos e Biotecnologia, 2008. 5p. (Embrapa Recursos Genéticos e Biotecnologia. Comunicado técnico, 178).

COSTA, M.L.N.; MACHADO, J. da C.; GUIMARÃES, R.M.; POZZA, E.A.; ORIDE, D. Inoculação de Fusarium oxysporum f. sp. phaseoli em sementes de feijoeiro através de restrição hídrica. Ciência e Agrotecnologia, v.27, p.1023-1030, 2003.

ETHUR, L.Z.; BLUME, E.; MUNIZ, M.F.B.; FLORES, M.G.V. Seleção de antagonistas fúngicos a Fusarium solani e Fusarium oxysporum em substrato comercial para mudas. Ciência Rural, v.37, p.1794-1797, 2007.

FERREIRA, D.F. SISVAR: um programa para análises e ensino de estatística. Revista Symposium, v.6, p.36-41, 2008.

FRANÇA NETO, J. de B.; HENNING, A.A. Qualidade fisiológica e sanitária de sementes de soja. Londrina: Embrapa-CNPSo, 1984. 39p. (Embrapa-CNPSo. Circular técnica, 9).

GOMES, D.P.; BARROZO, L.M.; SOUZA, A.L.; SADER, R.; SILVA, G.C. Efeito do vigor e do tratamento fungicida nos testes de germinação e de sanidade de sementes de soja. Bioscience Journal, v.25, p.59-65, 2009.

HARMAN, G.E. Myths and dogmas of biocontrol: changes in perceptions derived from research on Trichoderma harzianum T-22. Plant Disease, v.84, p.377-393, 2000.

HARMAN, G.E.; HOWELL, C.R.; VITERBO, A.; CHET, I.; LORITO, M. Trichoderma species - opportunistic, avirulent plant symbionts. Nature Reviews Microbiology, v.2, p.43-56, 2004.

HENNING, A.A.; FRANÇA NETO, J. de B. Problemas na avaliação de germinação de sementes de soja com alta incidência de Phomopsis sp. Revista Brasileira de Sementes, v.2, p.9-22, 1980.

HOYOS-CARVAJAL, L.; ORDUZ, S.; BISSETT, J. Growth stimulation in bean (Phaseolus vulgaris L.) by Trichoderma. Biological Control, v.51, p.409-416, 2009.

ITO, M.F.; CASTRO, J.L.; MENTEN, J.O.M.; MORAES, M.H.D. Importância do uso de sementes sadias de feijão e tratamento químico. O Agronômico, v.55, p.14-16, 2003.

LOBO JUNIOR, M.; GERALDINE, A.M.; CARVALHO, D.D.C.; COBUCCI, T. Uso de cultivares de feijão comum com arquitetura ereta e ciclo precoce para escape do mofo branco. Santo Antônio de Goiás: Embrapa Arroz e Feijão, 2009. 4p. (Embrapa Arroz e Feijão. Comunicado técnico, 182).

LOUZADA, G.A. de S.; CARVALHO, D.D.C.; MELLO, S.C.M.; LOBO JÚNIOR, M.; MARTINS, I.; BRAÚNA, L.M. Potencial antagônico de Trichoderma spp. originários de diferentes agroecossistemas contra Sclerotinia sclerotiorum e Fusarium solani. Biota Neotropica, v.9, p.145-149, 2009.

MARINO, R.H.; MESQUITA, J.B. Micoflora de sementes de feijão comum (Phaseolus vulgaris L.) provenientes do Estado de Sergipe. Revista Brasileira de Ciências Agrárias, v.4, p.252-256, 2009.

MARTINS-CORDER, M.P.; MELO, I.S. de. Antagonismo in vitro de Trichoderma spp. a Verticillium dahliae Kleb. Scientia Agricola, v.55, p.1-7, 1998.

MERTZ, L.M.; HENNING, F.A.; ZIMMER, P.D. Bioprotetores e fungicidas químicos no tratamento de sementes de soja. Ciência Rural, v.39, p.13-18, 2009.

OLIVEIRA, T.A.S.; CARVALHO, D.D.C.; MELLO, S.C.M. Avaliação da atividade antagônica in vitro de isolados de Trichoderma sp. para biocontrole de Sclerotinia sclerotiorum. Brasília: Embrapa Recursos Genéticos e Biotecnologia, 2008. 7p. (Embrapa Recursos Genéticos e Biotecnologia. Comunicado técnico, 177).

PARISI, J.J.D.; PATRÍCIO, F.R.A.; OLIVEIRA, S.H.F. de. Método do rolo de papel toalha modificado para a detecção de Sclerotinia sclerotiorum em sementes de feijão. Summa Phytopathologica, v.32, p.288-290, 2006.

POMELLA, A.W.V.; RIBEIRO, R.T.S. Controle biológico com Trichoderma em grandes culturas - uma visão empresarial. In: BETTIOL, W.; MORANDI, M.A.B. (Ed.). Biocontrole de doenças de plantas: uso e perspectivas. Jaguariúna: Embrapa Meio Ambiente, 2009. p.239-244.

REGRAS para análise de sementes. Brasília: Ministério da Agricultura, Pecuária e Abastecimento, 2009. 399p.

SAMUELS, G.J.; CHAVERRI, P.; FARR, D.F.; MCCRAY, E.B. Trichoderma online, systematic mycology and microbiology laboratory, ARS, USDA. Available at: <http://nt.ars-grin.gov/ taxadescriptions/keys/TrichodermaIndex.cfm $>$. Accessed on: 11 Dec. 2009.

SARTORI, A.F.; REIS, E.M.; CASA, R.T. Quantificação da transmissão de Fusarium moniliforme de sementes para plântulas de milho. Fitopatologia Brasileira, v.29, p.456-458, 2004.

TU, J.C. The role of white mold-infected white bean (Phaseolus vulgaris L.) seeds in the dissemination of Sclerotinia slcerotiorum (Lib.) de Bary. Journal of Phytopathology, v.121, p.40-50, 1988.

VINALE, F.; SIVASITHAMPARAM, K.; GHISALBERTI, E.L.; MARRA, R.;WOO, S.L.;LORITO,M.Trichoderma-plant-pathogen interactions. Soil Biology and Biochemistry, v.40, p.1-10, 2008.

ZUCCHI, T.D.; MELO, I.S. de. Controle biológico de fungos aflatoxigênicos. In: BETTIOL, W.; MORANDI, M.A.B. (Ed.). Biocontrole de doenças de plantas: uso e perspectivas. Jaguariúna: Embrapa Meio Ambiente, 2009. p.69-94.

Received on January 12, 2011 and accepted on June 16, 2011 